\title{
Microclimate of Developed Peatland of the Mega Rice Project in Central Kalimantan
}

\author{
Adi Jaya ${ }^{1}$, Takashi Inoue ${ }^{2}$, Suwido Hester Limin ${ }^{3}$, Untung Darung ${ }^{3}$ \\ and Irwan Sukri Banuwa ${ }^{4}$
}

Received 29 April $2009 /$ accepted 5 January 2010

\begin{abstract}
Microclimate of Developed Peatland of The Mega Rice Project in Central Kalimantan (A Jaya,T Inoue, SH Limin, U Darung and IS Banuwa): In Indonesia peatland covers an area of 16 to 27 Mha and this ecosystem is vitally linked to environmental and conservation issues, as well as its economic value for human survival. These peatlands are, however, the subject of various land use pressures, including forestry, agriculture, energy and horticulture. A field study was carried out 6 years after the end of failed peatland development project shows that inappropriate and unsustainable forms of peatland management have resulted in degradation of the natural forest vegetation, draw-down of the peat water table, increase of peat surface and air temperatures and recurrent surface and ground fires. Implications of microclimate for possible restoration options.
\end{abstract}

Keywords: Peatlands, soil moisture, temperature

\section{INTRODUCTION}

Peatlands are wetland ecosystems characterised by accumulation of organic matter that is produced and deposited at a faster rate than it can be decomposed (Gore 1983). Peat formation in the tropics commences under conditions of constant waterlogging or in wet coastal areas where organic matter is produced in abundance by an adapted vegetation of mangroves, grasses or swamp forest trees (Driessen 1977; Radjagukguk 2000).

Approximately 12 percent of the global peatland area occurs in humid tropical zones, mainly in mainland East Asia, Southeast Asia, the Caribbean and Central America, South and southern Africa (Rieley et al. 1996). Peatland in Indonesia covers about 16 to 27 Mha (Radjagukguk 1992; Rieley et al. 1996). These ecosystems are vitally linked to conservation issues such as carbon sequestration affecting global climate change, and provision of key habitat for a diverse range of the world's flora and fauna. They are also the source of a significant portion of the freshwater and many economic resources vital to human survival. In addition, peatland ecosystems are important for water resources conservation since their ability to store water is very high and can be up to 8 times of the peat volume (Widajaja-Adhi 1997). Tropical peatlands, however are also the subject to land use pressures including forestry development and agriculture on them as well as extraction for energy and horticulture (MacDicken 2002). In 1996, 1.5 Mha of Peatland in Central Kalimantan was developed for rice production. This project failed and was closed down in 1999 but left on legacy of habitat destruction and fire occurrence.

Conservation of vast peat land area for the carbon stored in them as well as for water protection seems to be one solution for the future. It seems, however that even of conservation show a great and significant success, the loss of forest still occurs at the alarming rate. The involvement of local communities therefore is important to the success of conservation of tropical peat land.

The purpose of this research is to study the environmental condition of the developed peat land

\footnotetext{
${ }^{1}$ Post Graduate Program, The University of Palangka Raya, Central Kalimantan, email: adijaya_unpar@yahoo.co.id

${ }^{2}$ Faculty of Agriculture, University of Hokkaido, Japan

${ }^{3}$ Faculty of Agriculture, University of Palangka Raya, Indonesia

${ }^{4}$ Faculty of Agriculture, Universitas of Lampung, Jl. Sumantri Brojonegoro No. 1 Bandar Lampung 34145

J Trop Soils, Vol. 15, No. 1, 2010: 63-71

ISSN 0852-257X
} 


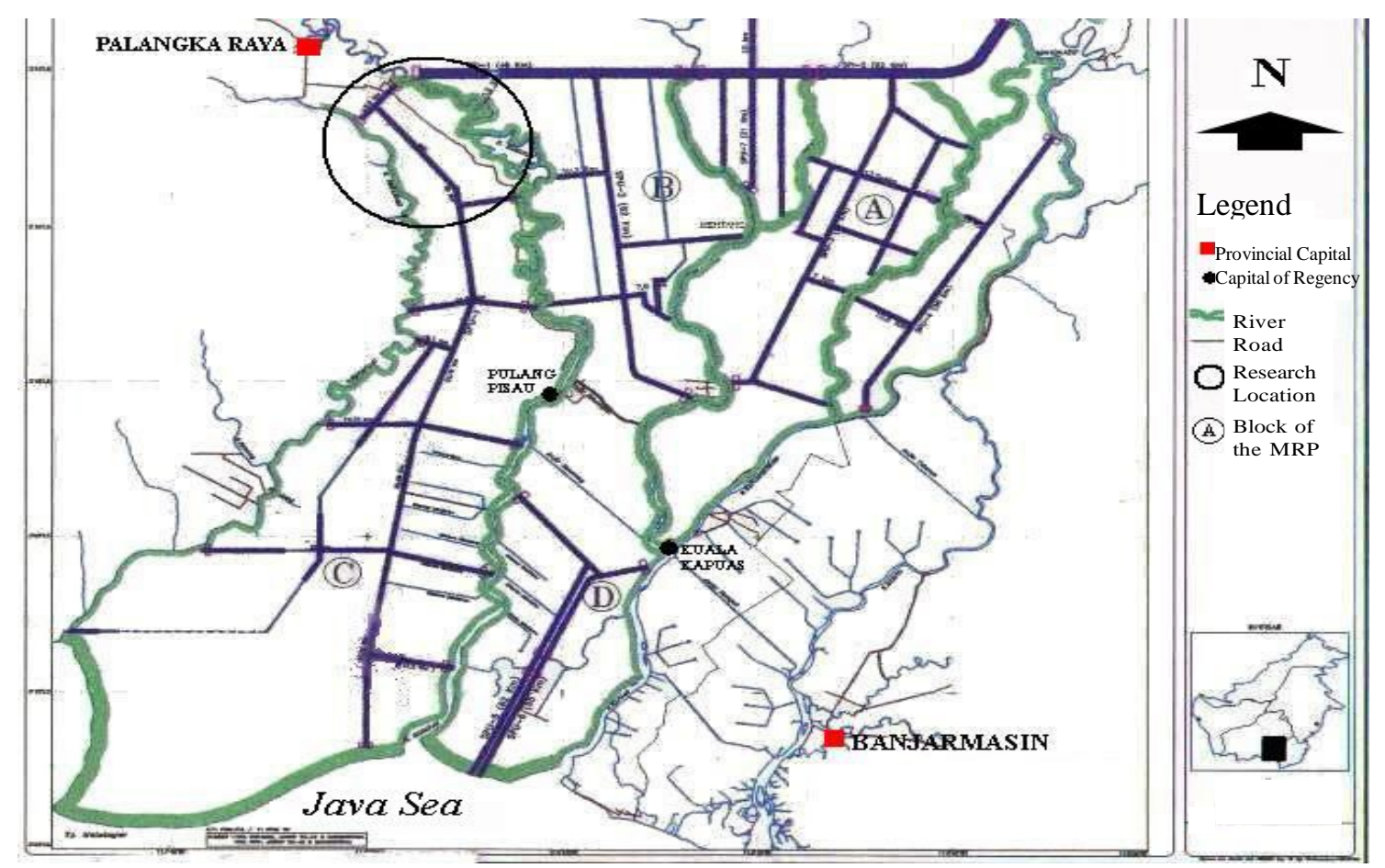

Figure 1. Map of research location.

area and various impacts after the commencement of development of the ex-Mega Rice Project (the MRP) in 1996 especially on microclimate aspect.

\section{MATERIALS AND METHODS}

Research was conducted in the area of ex-MRP Central Kalimantan, which opened in 1996 through a Presidential Decree 82/1995 to develop the area of more than one million hectares for food production, especially rice. The Mega Rice Project covers an area of 1,457,100 ha area with a boundary Sebangau River in the West, Java Sea in the South, Barito River in eastern and Primary Channel Master (SPI) in the northern part (Figure 1). The area of the MRP is divided into 4 areas of work, Block A (227,100 ha), Block B (161,480 ha), Block C (568,635 ha) and Block D (162,278 ha) plus the Block E (337,607 ha) as a buffer zone adjacent to North of SPI.

Data of peat soil surface temperature was measured with automatic recording devices at intervals of every one-hour observation, and conducted in forested peat, burnt forest (re-growing forest) in the northern part of Block $\mathrm{C}$ of the ex-MRP and agricultural areas in the Village of Kalampangan. Rainfall was measured using a measuring type of tipping bucket rain gauge set in forest areas, and open areas ex-fire in Block $\mathrm{C}$ of the ex MRP and 64
Kalampangan village farming areas. Thermometer to measure soil and air temperature set at the same location with the logger and set to record every onehour intervals. Soil moisture was only installed in agricultural areas of Kalampangan village and observation sensors for soil moisture were installed at a depth of 10, 20,30, and $40 \mathrm{~cm}$.

\section{RESULTS AND DISCUSSION}

\section{Soil Moisture}

Data for hourly soil moisture recorded from 30 September 1999 until 19 February 2004 in the agriculture area of Kalampangan village adjacent to the northern area of Block C of ex-the MRP are presented in Figure 2.

Data analysis using paired t-tests (Tables 1 and 2) show that the thickness of the peat layer has highly significant effects on soil moisture. The volumetric soil moisture at $10 \mathrm{~cm}$ depth varies from 13.50 to $68.98 \%$, with an average of $39.87 \%$. The soil moisture in this layer has the highest fluctuation as shown by the highest standard deviation (13.76\%). At $20 \mathrm{~cm}$ depth soil moisture ranges from 37.84 to $68.64 \%$ with an average of $58.56 \%$, showing a higher difference of $18.69 \%$ of soil water content compared to $10 \mathrm{~cm}$ depth. 

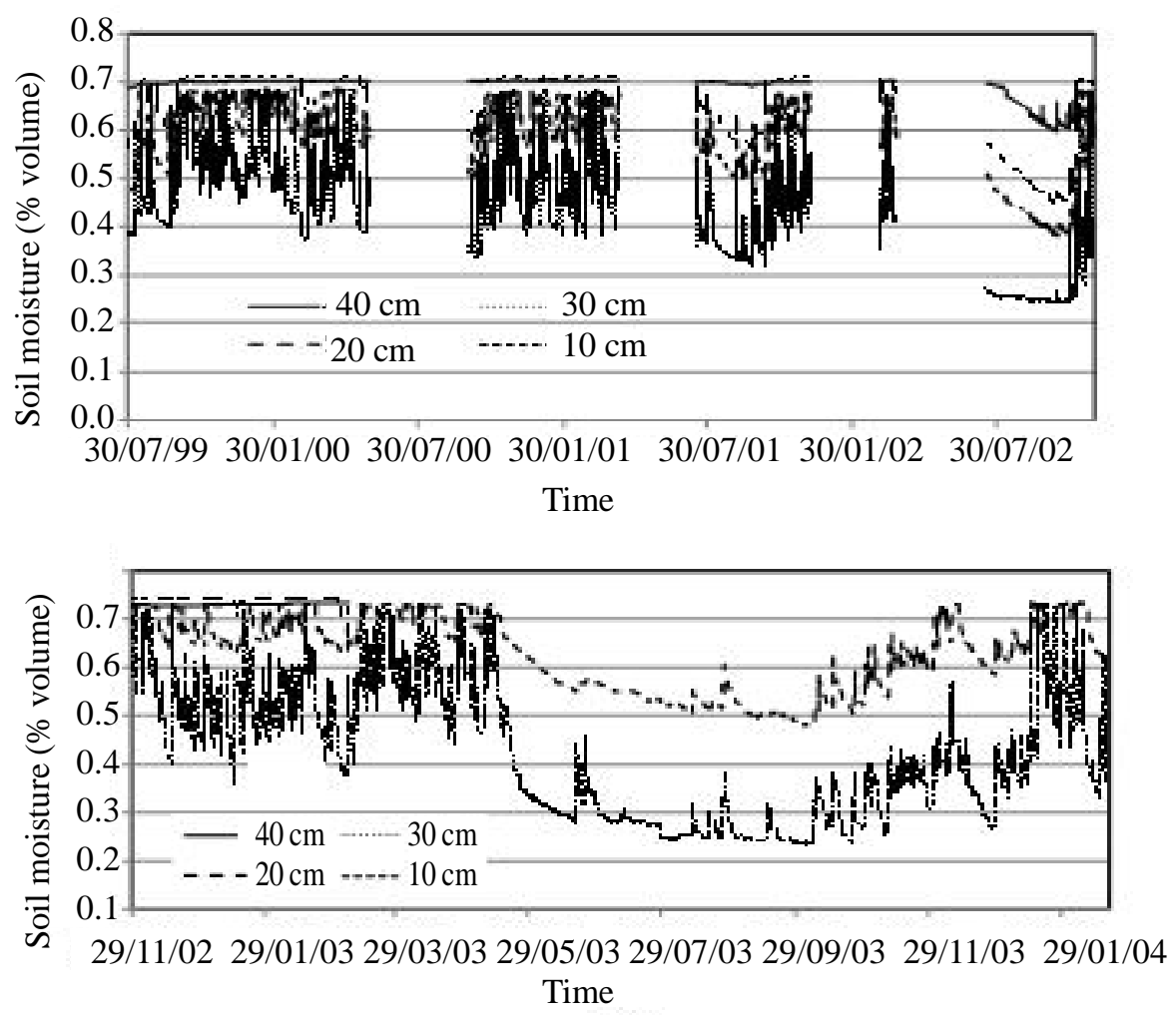

Figure 2. The volumetric soil moisture in several peat layers in agriculture area.

Table 1. The range of volumetric soil moisture in different peat layers in agriculture area.

\begin{tabular}{ccc}
\hline Depth of sensor $(\mathrm{cm})$ & $\begin{array}{c}\text { Range of soil moisture } \\
(\% \text { volume })\end{array}$ & $\begin{array}{c}\text { Average of soil moisture } \\
(\% \text { volume })\end{array}$ \\
\hline 10 & $24.16-68.79$ & $44.31^{\mathrm{a}} \pm 11.65$ \\
20 & $37.84-68.64$ & $58.70^{\mathrm{b}} \pm 8.81$ \\
30 & $44.76-71.07$ & $65.69^{\mathrm{c}} \pm 7.71$ \\
40 & $59.57-70.55$ & $69.21^{\mathrm{d}} \pm 2.35$ \\
\hline
\end{tabular}

Note: The different letters shows mean difference is significant at the 0.01 level based on Table 2 .

Table 2. Paired t-tests of volumetric soil moisture in different peat layer in agriculture area of Kalampangan village.

\begin{tabular}{|c|c|c|c|c|c|c|c|c|}
\hline & \multicolumn{5}{|c|}{ Paired D ifferences } & \multirow{3}{*}{$\mathrm{t}$-value } & \multirow{3}{*}{$\mathrm{df}$} & \multirow{3}{*}{$\begin{array}{l}\text { Sig. (2- } \\
\text { tailed) }\end{array}$} \\
\hline & \multirow[t]{2}{*}{ Mean } & \multirow[t]{2}{*}{ Std. Dev. } & \multirow{2}{*}{$\begin{array}{l}\text { Std. } \\
\text { Error } \\
\text { Mean }\end{array}$} & \multicolumn{2}{|c|}{$\begin{array}{l}99 \% \text { Confidence } \\
\text { Interval of the } \\
\text { Difference }\end{array}$} & & & \\
\hline & & & & Lower & Upper & & & \\
\hline $40 \mathrm{~cm}-30 \mathrm{~cm}$ & 0.0305 & 0.0575 & 0.0004 & 0.0297 & 0.0312 & 77.473 & 21.399 & 0.000 \\
\hline $40 \mathrm{~cm}-20 \mathrm{~cm}$ & 0.0989 & 0.0713 & 0.0005 & 0.0979 & 0.0999 & 202.914 & 21.399 & 0.000 \\
\hline $40 \mathrm{~cm}-10 \mathrm{~cm}$ & 0.2454 & 0.1018 & 0.0007 & 0.2440 & 0.2468 & 352.552 & 21.399 & $0, .000$ \\
\hline $30 \mathrm{~cm}-20 \mathrm{~cm}$ & 0.0684 & 0.0349 & 0.0002 & 0.0680 & 0.0689 & 286.691 & 21.399 & 0.000 \\
\hline $30 \mathrm{~cm}-10 \mathrm{~cm}$ & 0.2149 & 0.0742 & 00005 & 0.2139 & 0.2159 & 423.870 & 21.400 & 0.000 \\
\hline $20 \mathrm{~cm}-10 \mathrm{~cm}$ & 0.1672 & 0.0683 & 0.0004 & 0.1665 & 0.1680 & 421.962 & 29.698 & 0.000 \\
\hline
\end{tabular}




\section{A Jaya et al.: Microclimate of Developed Peatland of Kalimantan}

The results of correlation analysis between volumetric soil moisture in several peat layers and water table and air temperature are shown in Table 3. The volumetric soil moisture at all peat layers measured has a significantly negative correlation with the depth of water table. The deeper the site of measurement the stronger the correlation is. In contrast, temperature only shows a correlation with soil moisture at peat depths of 10 and $20 \mathrm{~cm}$.

The peat in the agriculture area, based on continuous measurement, has a wide range of soil moisture from $0.1350 \mathrm{~m}^{3} \mathrm{~m}^{-3}$ at a depth of $10 \mathrm{~cm}$ to $0.7107 \mathrm{~m}^{3} \mathrm{~m}^{-3}$ at $30 \mathrm{~cm}$. In comparison, the measurement at a depth of $10 \mathrm{~cm}$, Hatano et al. (2004) showed that soil moisture in the agriculture area ranged from 0.326 to $0.367 \mathrm{~m}^{3} \mathrm{~m}^{-3}$, which was higher than the natural forest $\left(0.175 \mathrm{~m}^{3} \mathrm{~m}^{-3}\right)$ and regrowing forest $\left(0.216 \mathrm{~m}^{3} \mathrm{~m}^{-3}\right)$. Kurnain et al. (2002) stated that land use clearly influences the gravimetric field water content of peat because, in pristine forest of Central Kalimantan, Indonesia, it was $574 \%$ and significantly higher compared to clear cut peat forest $(203 \%)$, cultivated peatlands $(438 \%)$ and burnt peat forest (305\%). The water table level has a significant effect upon soil moisture, which is higher closer to the water table. In contrast, temperature only affects soil moisture to a depth of $20 \mathrm{~cm}$ below the surface.

The moisture condition of peat soil has an important role in soil management since most physical characteristics are related to the moisture conditions. Soil moisture in peat soil directly influences the degree of subsidence, pore geometry, buffer capacity and soil thermal characteristics (Bouman and

Table 3. Summary of correlation analysis between volumetric soil moisture, water table depth and air temperature at different peat depths.

\begin{tabular}{llcc}
\hline & & Water Table & Air Temperature \\
\hline $40 \mathrm{~cm}$ & Pearson Correlation & $-0.427^{* *}$ & -0.003 \\
& Sig. (2-tailed) & 0.000 & -0.864 \\
& $\mathrm{~N}$ & 2379 & 3460 \\
$30 \mathrm{~cm}$ & Pearson Correlation & $-.402^{* *}$ & -0.015 \\
& Sig. (2-tailed) & 0.000 & 0.376 \\
& $\mathrm{~N}$ & 2379 & 3460 \\
$20 \mathrm{~cm}$ & Pearson Correlation & $-0.374^{* *}$ & $-0.081^{* *}$ \\
& Sig. (2-tailed) & 0.000 & 0.000 \\
& N & 2379 & 3460 \\
$10 \mathrm{~cm}$ & Pearson Correlation & $-0.255^{* *}$ & $-0.078^{* *}$ \\
& Sig. (2-tailed) & 0.000 & 0.000 \\
& $\mathrm{~N}$ & 2379 & 3460 \\
\hline
\end{tabular}

** Correlation is significant at the 0.01 level (2-tailed).
Driessen 1985). Soil moisture has a significant role in carbon balance. The emission rate of $\mathrm{CO}_{2}$, for example, depends on the moisture condition (Toyota and Okazaki 2004). For the tropical peatland of Central Kalimantan, Indonesia, it was found that the largest $\mathrm{CO}_{2}$ emission occurs at a water content of $65 \%$ in both natural and re-growing forest while, in the burnt area, it takes place with a water content of $85 \%$. In addition, based on work in the same region, Hatano et al. (2004) found that soil moisture positively affects methane flux, but has only a moderately significant correlation with $\mathrm{NO}_{2}$ flux.

\section{Temperature}

\section{Air Temperature}

Hourly measurements of air temperature were recorded from September 2000 to May 2005 within the forest, regrowing forest, destroyed forest and agriculture area. A continuous record of data is not available because the equipment malfunctioned at certain times. From the data available the variations in average daily temperatures under the four types of land cover are presented in Figure 3.

\section{Daily Temperature}

Table 4 shows the average daily temperature and its fluctuation in the agriculture area and destroyed forest are higher than in the forest and regrowing forest. In the agriculture area, the average temperature ranged from 23.79 to $31.49^{\circ} \mathrm{C}$ with an average of 27.47 $\pm 1.20^{\circ} \mathrm{C}$. From the examination of the entire data as shown in Figure 4, most temperatures $(88.35 \%)$ within the agriculture area were between 26 to $30^{\circ} \mathrm{C}$. In the destroyed forest, the range of temperature was between 22.82 and $30.30^{\circ} \mathrm{C}$ and the average of 27.09 $\pm 1.11^{\circ} \mathrm{C}$. Most of the temperatures $(82.74 \%)$ in the destroyed forest lay between 26 to $30^{\circ} \mathrm{C}$. In contrast, in those areas with denser vegetation cover, temperature ranges from 23.27 to 28.49 (averages of

Table 4. Average daily air temperatures within several land-uses.

\begin{tabular}{lcccc}
\hline Location & Means & Std. Dev. & Min. & Max. \\
\hline Agriculture & 27.47 & 1.20 & 23.79 & 31.49 \\
Destroyed Forest & 27.09 & 1.11 & 22.82 & 30.30 \\
Forest & 25.87 & 0.84 & 23.27 & 28.49 \\
Regrowing Forest & 27.00 & 1.43 & 22.67 & 31.41 \\
\hline
\end{tabular}



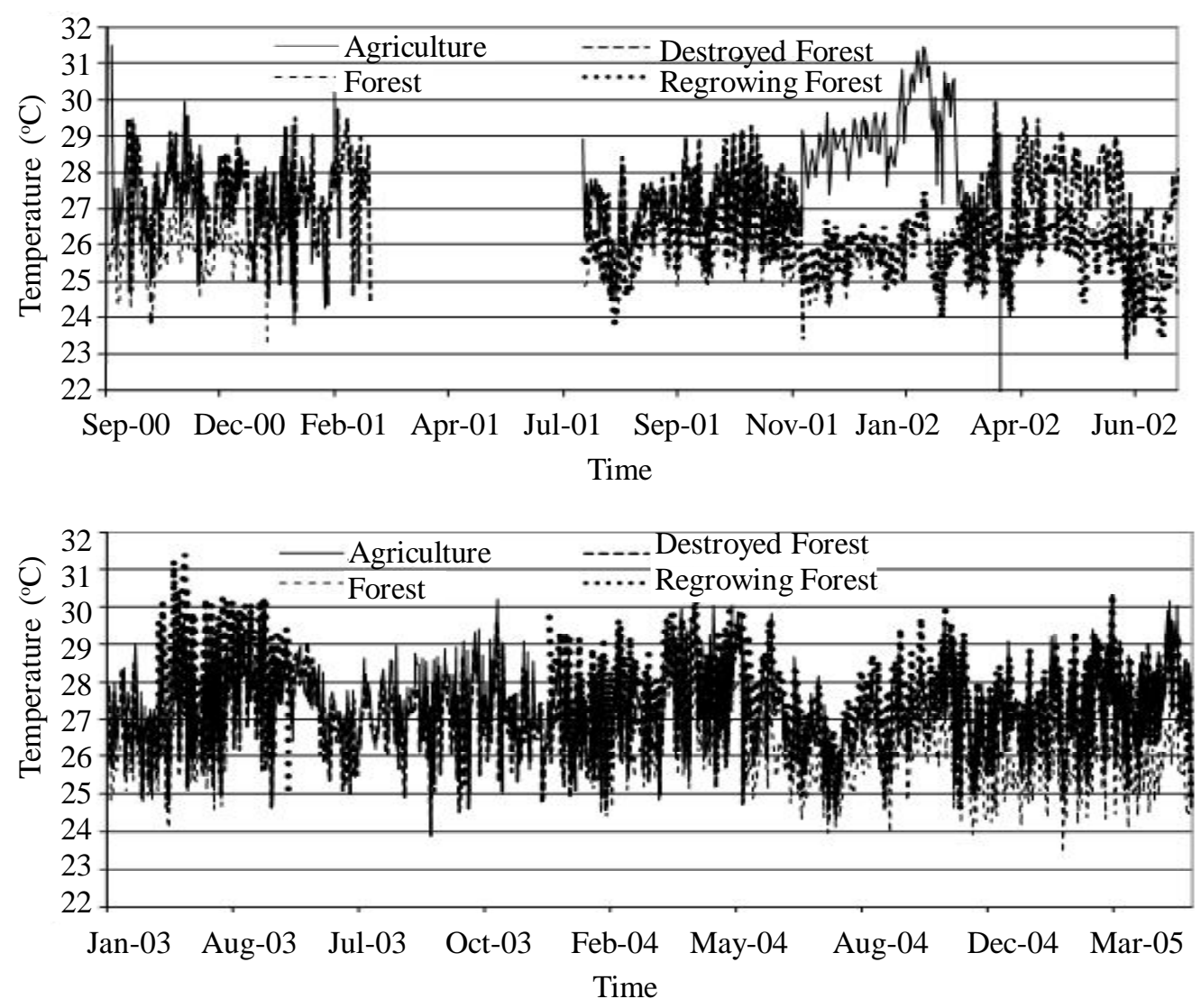

Figure 3. Fluctuation of air temperature on several land cover from September 2000-May 2005.

$\left.25.87 \pm 0.84^{\circ} \mathrm{C}\right)$ in the forest and from 22.67 to 31.41 (averages of $27.00 \pm 1.43^{\circ} \mathrm{C}$ ) in the regrowing forest. Most of temperature values in the forest $(98.89 \%)$ and regrowing forest $(98.81 \%)$ lie between 24 and $28^{\circ} \mathrm{C}$.

The paired sample t-tests, presented in Table 5, show that there are significant differences in the means of daily temperature between each location, except between agriculture area and destroyed forest.

\section{Hourly Temperature}

Table 6 shows the data of average hourly air temperatures were obtained within regrowing forest, agriculture area, destroyed forest and forest area. The highest average hourly temperature and its fluctuation were in the regrowing forest $\left(27.66 \pm 4.72^{\circ} \mathrm{C}\right)$ following by agriculture area $\left(27.37 \pm 4.86^{\circ} \mathrm{C}\right)$, destroyed forest $\left(26.99 \pm 4.23^{\circ} \mathrm{C}\right)$, and forest area $\left(25.92 \pm 2.75^{\circ} \mathrm{C}\right)$.

Table 5. Paired samples test on the daily air temperature between locations.

\begin{tabular}{lcccccc}
\hline \multirow{2}{*}{ Locations } & \multicolumn{3}{c}{ Paired Differences } & \multirow{2}{*}{ t-value } & \multirow{2}{*}{ df } & \multirow{2}{*}{ Sig. (2-tailed) } \\
\cline { 2 - 5 } & Mean & Std. Dev. & Std. Error Mean & & & \\
\hline Agric-DestFor & 0.2581 & 0.4723 & 0.0138 & 18.662 & 1165 & 0.000 \\
Agric-For & 1.6104 & 0.9063 & 0.0295 & 54.680 & 946 & 0.000 \\
Agric-RegrFor & 0.2828 & 1.4093 & 0.0482 & 5.864 & 853 & 0.000 \\
DestFor-For & 1.1690 & 0.6360 & 0.0204 & 57.339 & 972 & 0.000 \\
DestFor-RegrFor & -0.1613 & 1.1498 & 0.0385 & -4.180 & 887 & 0.000 \\
For- RegrFor & -1.1184 & 1.0233 & 0.0340 & -32.896 & 905 & 0.000 \\
\hline
\end{tabular}

Note $:$ Agric $=$ Agriculture, DestFor $=$ Destroyed forest, For $=$ Forest, REGR $=$ Regrowing forest. 


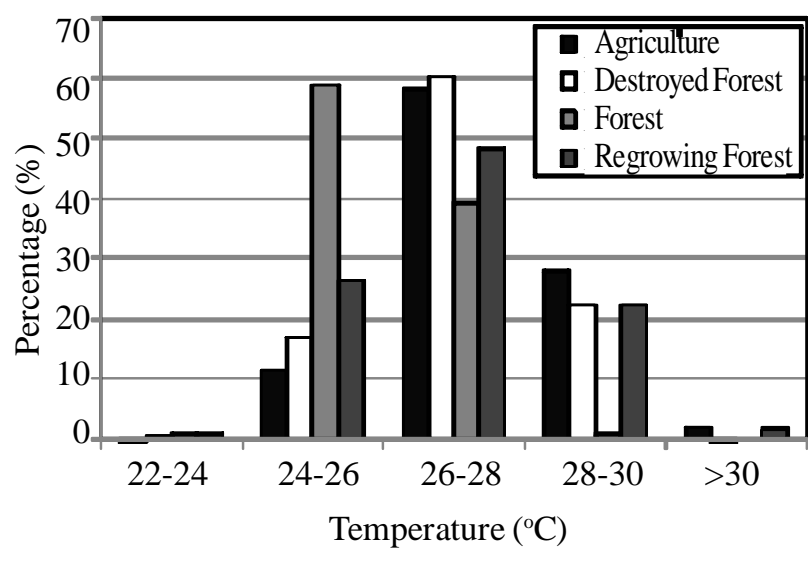

Figure 4. Frequency analysis of daily air temperature within several land-uses.

The pattern of diurnal temperature fluctuation in all four land cover types was similar. Figure 5 shows the average fluctuation of air temperature for July and August 2001 (dry season) and March 2002 (rainy season). The temperature was almost stable until 6 or 7 am and increased slightly reaching a maximum at 12 a.m. to 2 p.m. with a temperature of $36.26^{\circ} \mathrm{C}$ (destroyed forest), $34.09^{\circ} \mathrm{C}$ (agriculture area), $31.71^{\circ} \mathrm{C}$ (regrowing forest) and $29.21^{\circ} \mathrm{C}$ (forest) in the dry season. In the rainy season, however, the maximum temperature was slightly lower at $33.94^{\circ} \mathrm{C}$ (destroyed forest), $32.76^{\circ} \mathrm{C}$ (agriculture), $28.98^{\circ} \mathrm{C}$ (regrowing forest) and $28.43^{\circ} \mathrm{C}$ (forest). Temperatures decrease until around $6 \mathrm{p} . \mathrm{m}$. and remain relatively constant until 7 a.m. Both the data on daily and diurnal temperature fluctuations confirmed the significance of forest or vegetation cover to reduce the temperature.

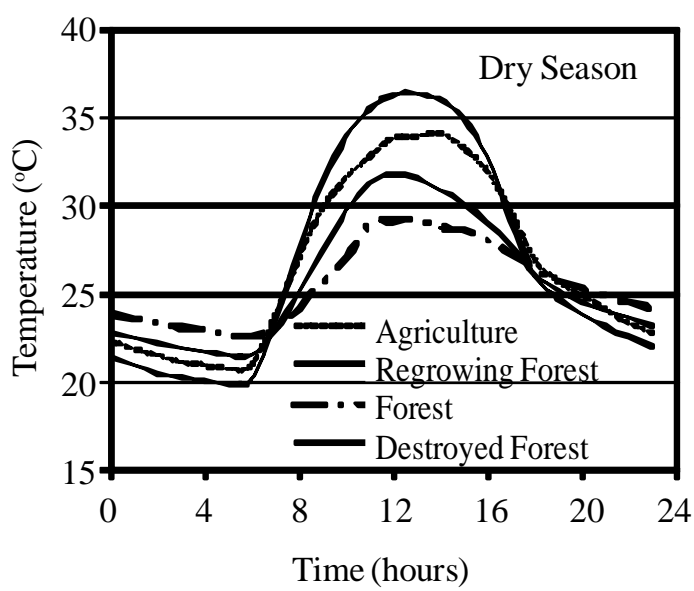

Table 6. Hourly air temperature $\left({ }^{\circ} \mathrm{C}\right)$ within several land-uses.

\begin{tabular}{lcccc}
\hline Locations & Means & Std. Dev. & Min. & Max. \\
\hline Agriculture & 27.37 & 4.86 & 16.00 & 44.89 \\
Destroyed Forest & 26.99 & 4.24 & 15.23 & 42.94 \\
Forest & 25.92 & 2.75 & 19.42 & 38.32 \\
Regrowing Forest & 27.66 & 4.72 & 16.33 & 41.05 \\
\hline
\end{tabular}

\section{Peat Surface Temperature}

The data for peat surface temperature $(0-20 \mathrm{~cm})$ are only available for the agriculture area, forest and regrowing forest from $1^{\text {st }}$ March to $15^{\text {th }}$ July 2002 owing to malfunctioning of the thermometer. The peat and air temperatures at the three locations are depicted in Figure 8 and a summary of descriptive statistics is presented in Table 7. Peat surface temperature is higher than air temperature in the agriculture area and regrowing forest while, in the forest, peat surface temperature is lower than air temperature. The highest average surface peat temperature of $30.22^{\circ} \mathrm{C}$ occurs in the agriculture area, following by regrowing forest $\left(26.71^{\circ} \mathrm{C}\right)$ and forest $\left(22.88^{\circ} \mathrm{C}\right)$.

The analysis of means by using paired samples test between air and peat temperature in agriculture area, forest and re-growing forest and also peat surface temperature between the three locations is presented in Table 8. This shows a highly significant different between the average air and peat surface temperatures within each location and between all locations.

The pattern of diurnal peat surface temperature fluctuations in the three land cover types differs. The

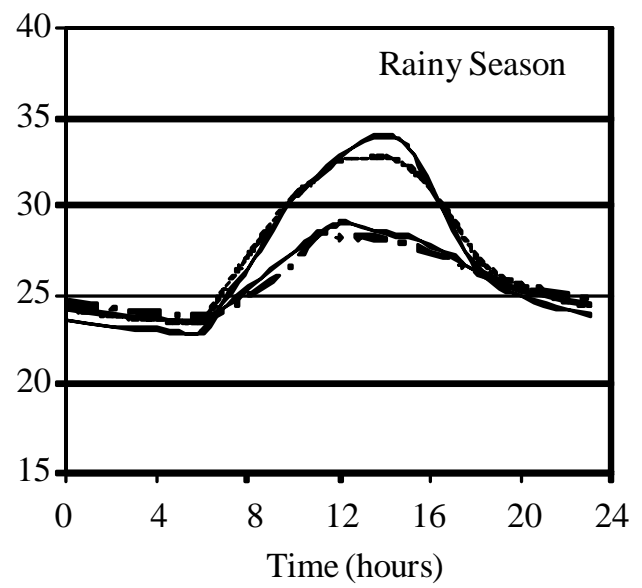

Figure 5. An average day period of air temperature fluctuation, taken from dry season (JulyAugust 2001) and rainy season (March 2002). 


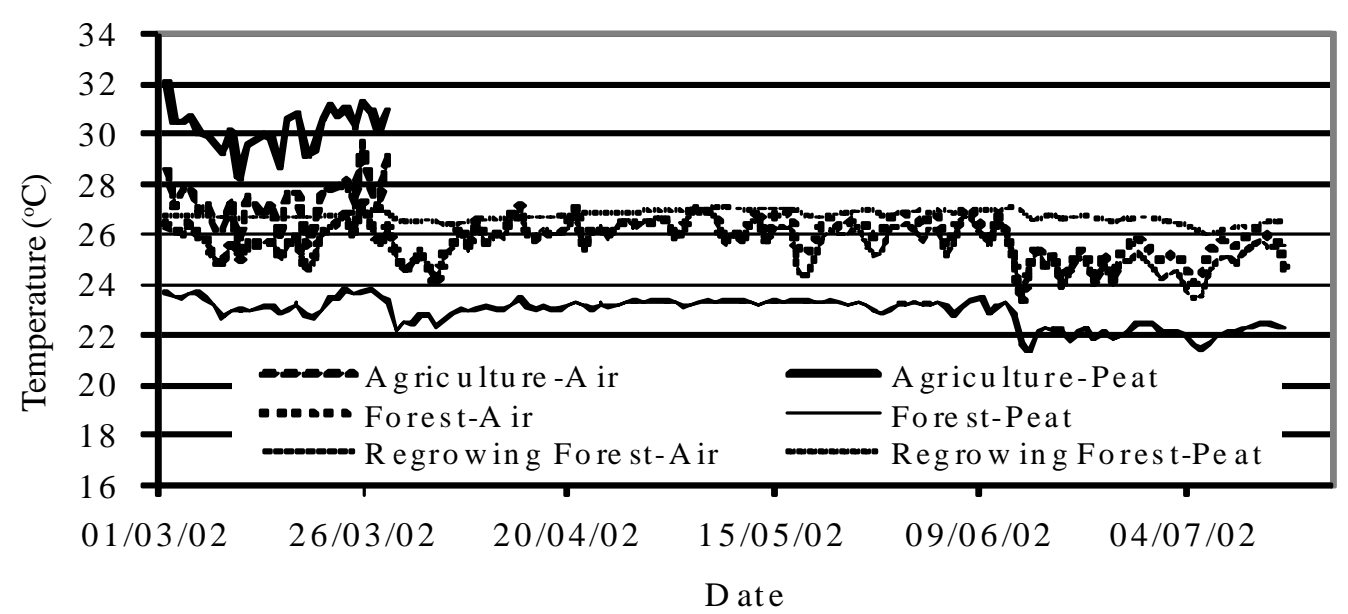

Figure 6. Peat surface and air temperature in the three locations from March to July 2002.

average data of hourly measurement within a month is used to show this pattern. Compared to the pattern of air temperature, in general, the pattern of peat temperature shows increases that are about 1 to 2 hours behind. The peat surface in the agriculture area during the rainy season (March 2002) had a relatively stable temperature between 27.5 and $28.8^{\circ} \mathrm{C}$ until 7 am and then increases slightly reaching a maximum of $33.67^{\circ} \mathrm{C}$, between 2.00 and 3.00 p.m., after which it decreases slowly to $29.15^{\circ} \mathrm{C}$ at 11.00 p.m. The peat surface temperature at forest area is stable at a range of temperature between 22.98 and $23.41^{\circ} \mathrm{C}$ over 24 hours periods, while the same pattern is also found at the regrowing forest area with a range between 26.72 and $26.75^{\circ} \mathrm{C}$.

Vegetation cover on tropical peatland has a significant influence on the average daily air and peat surface temperature at the three study sites. Open peatland areas, such the agriculture area with an average of $27.62 \pm 1.38^{\circ} \mathrm{C}$ and destroyed forest with an average of $27.20 \pm 1.12^{\circ} \mathrm{C}$ have much higher temperatures and variation than those with a vegetation cover (Rieley et al. 1996; Takahashi and Yonetani 1997) such as regrowing forest (26.04 \pm $\left.0.81^{\circ} \mathrm{C}\right)$ and forest site $\left(25.72 \pm 0.72^{\circ} \mathrm{C}\right)$. Similar ranges of temperature were also found by Hirano et al. (2003) who obtained an air temperature of $26.5^{\circ} \mathrm{C}$ in a forested area at a height of 41.7 metres above the peat surface at the northern area of Block $\mathrm{C}$ of ex-the MRP.

Within the forested area, the average peat surface temperature was $2.96^{\circ} \mathrm{C}$ lower than the average air temperature while, for the developed peatland area (e.g. the agriculture and re-growing forest areas), the average peat surface temperature was between $1.09-2.97^{\circ} \mathrm{C}$ higher than the average air temperature in the same locations. From these data, it is clear that the loss or changes of vegetation cover in peatlands is strongly influencing the peat surface temperature. The existence of plants that grow on the peat swamp alters the heat and water balance of the soil on which they grow. It has been found, for example, that peat swamp forest reduces the ground albedo significantly contributing to the frequency of rainfall that decreases when forest is cleared. With reference to radiation exchanges, there are marked differences between forested and deforested areas with respect to their solar radiation exchange (Silvius and Giesen 1992).

Table 7. Descriptive statistics of air and peat surface temperature within three land uses.

\begin{tabular}{lrcccc}
\hline & $\mathrm{N}$ & Minimum & Maximum & Means & Std. Dev. \\
\hline Agriculture-Air & 27 & 25.13 & 29.66 & 27.25 & 1.03 \\
Agriculture-Peat & 27 & 28.22 & 32.08 & 30.22 & 0.86 \\
Forest- Air & 137 & 23.27 & 29.35 & 25.84 & 0.85 \\
Forest- Peat & 137 & 21.18 & 23.78 & 22.88 & 0.57 \\
Regrowing Forest- Air & 136 & 23.28 & 27.26 & 25.62 & 0.83 \\
Regrowing Forest- Peat & 136 & 25.98 & 27.09 & 26.71 & 0.21 \\
\hline
\end{tabular}




\section{A Jaya et al.: Microclimate of Developed Peatland of Kalimantan}

Table 8. Paired samples test between air and peat temperature within each land use and peat temperature between three land uses.

\begin{tabular}{|c|c|c|c|c|c|c|}
\hline \multirow{2}{*}{ Locations } & \multicolumn{3}{|c|}{ Paired Differences } & \multirow{2}{*}{ t-value } & \multirow{2}{*}{ df } & \multirow{2}{*}{ Sig. (2-tailed) } \\
\hline & Mean & Std. Dev. & Std. Error Mean & & & \\
\hline AgrA - AgrP & -2.961 & 0.46179 & 0.08887 & -33.32 & 26 & 0.000 \\
\hline ForA-ForP & 2.968 & 0.63409 & 0.05417 & 54.79 & 136 & 0.000 \\
\hline RegA-RegP & -1.091 & 0.73323 & 0.06287 & -17.35 & 135 & 0.000 \\
\hline AgrP-ForP & 6.952 & 0.67002 & 0.12895 & 53.91 & 26 & 0.000 \\
\hline AgrP-RegP & 3.481 & 0.82089 & 0.15798 & 22.04 & 26 & 0.000 \\
\hline PorP-RegP & -3.838 & 0.45364 & 0.03890 & -98.67 & 135 & 0.000 \\
\hline
\end{tabular}

Note: AgrA = Air temperature at agriculture area, $\operatorname{AgrP}=$ Peat surface temperature at agriculture area, ForA = Air temperature at forest area, ForP $=$ Peat surface temperature at forest area, $\operatorname{Reg} \mathrm{A}=$ Air temperature at regrowing forest area, $\mathrm{RegP}=$ Peat surface temperature at regrowing forest area.

Variations also occurred in both air and peat surface temperature under different land conditions. The highest variation was in the agriculture area, followed by destroyed forest, re-growing forest and the forested area. This again supports the importance of vegetation cover in controlling temperature fluctuation. Compared to air temperature, however, peat surface temperature is higher than air temperature but shows a smaller variation for all sites.

The higher temperatures will have an effect to the increase of oxidation process and, furthermore, will lead to higher gas efflux rates, especially $\mathrm{CO}_{2}$ and methane. In sub arctic/boreal fen, Moore et al. (1990) reported that soil temperature has a positive correlation with methane flux, while Otter and Scholes (2000) found a similar relationship between methane flux and temperature for the wetlands of South Africa. In tropical peatland of Central Kalimantan, Indonesia, Hatano et al. (2004) reported that soil temperature has a moderate significant correlation with $\mathrm{CO}_{2}$ flux and $\mathrm{N}_{2} \mathrm{O}$ as well as a positive correlation with methane flux.

\section{CONCLUSIONS}

The results of this study showed changes in land use as a result of the MRP activities cause changes in microclimate conditions in the peatland area. Fluctuation of air temperature and peat surface temperature significantly affected by the condition of vegetation covered on it. The loss or reduction in vegetation cover is significantly affect the peat surface temperature and this will also related to the fluctuations on peat surface moisture. Peat surface moisture fluctuations are correlated with fluctuations in air temperature and peat surface temperature.

\section{REFERENCES}

Bouman SAM and PM Driessen. 1985. Physical properties of peat soils affecting rice-based cropping system. In: Soil Physics and Rice. IRRI, Los Banos, Philippines, pp. 71-84.

Driessen PM. 1977. Peat soil. In: Soils and Rice. IRRI, Los Banos, Philippines, pp. 763-779.

Gore AJP. 1983. Introduction. In: AJP Gore (ed). Mires: Swamp, Bog, Fen and Moor. Ecosystems of the World Vol. 4A. Elsevier Sci. Publ. Co., Amsterdam, pp. 1-34. Hatano R, T Morishita, U Darung, SH Limin and S Anwar. 2004. Impact of agriculture and wildfire on $\mathrm{CO}_{2}, \mathrm{CH}_{4}$ and $\mathrm{N}_{2} \mathrm{O}$ emissions from tropical peat soil in Central Kalimantan, Indonesia. Field Science Center for Northern Biosphere, Hokkaido University, Sapporo, Japan, pp. 1-14.

Hirano T, M Osaki, H Tani, R Hirata, J Mogami, M Gamo, T June, H Segah, IP Kulu and SH Limin. 2003. Microclimate of a tropical peatswamp forest in Central Kalimantan, Indonesia from 2001 to 2002. In: M. Osaki (ed). Environmental Conservation and Land Use Management of Wetland Ecosystem in Southeast Asia. Annual Report for April 2002-March 2003. Hokkaido University and Research Center for Biology, LIPI, pp. 80-87.

Kurnain A, T Notohadikusumo, B Radjagukguk and S Hastuti. 2002. The state of decomposition of tropical peat soil under cultivated and fire damaged peatlands. In: JO Rieley and SE Page (eds). Proceedings of the International Symposium on Tropical Peatlands: Peatlands for People - Natural Resource Functions and Sustainable Management. BBPT and Indonesian Peat Association, pp. 168-178. 
MacDicken K. 2002. Cash for tropical peat: Land use change and forestry projects for climate change mitigation. In: JO Rieley and SE Page (eds). Proceedings of the International Symposium on Tropical Peatlands: Peatlands for People - Natural Resource Functions and Sustainable Management. BBPT and Indonesian Peat Association, pp. 1-6.

Moore TR, N Roulet and R Knowles. 1990. Spatial and temporal variations of methane flux subartic/northern boreal fen. Global Biogeochem Cycl 4 (1): 29-46.

Otter LB and MC Scholes. 2000. Methane sources and sinks in a periodically flooded South African savanna. Global Biogeochem Cycl 14 (1): 97-111.

Radjagukguk B. 1992. Utilisation and management of peatlands in Indonesia for agriculture and forestry. In: Proceedings of the International Symposium on Tropical Peatland. Kuching, Sarawak, Malaysia. May 1991. Malaysia, Ministry of Agriculture, MARDI, pp. 21-27.

Rieley JO, AA Ahmad-Shah and MA Brady. 1996. The extent and nature of tropical peat swamps. In: E Maltby, CP Immirzi and RJ Safford. Tropical Lowland Peatlands of Southeast Asia. Proceedings of a
Workshop on Integrated Planning and Management of Tropical Lowland Peatlands. IUCN, pp. 17-53.

Silvius MJ and W Giesen. 1992. Towards integrated management of Sumatran peat swamp forests. Paper prepared for Workshop on Sumatra Environment and Development. Bogor, 16-18 September 1992.

Takahashi H and Y Yonetani. 1997. Studies on microclimate and hydrology of peat swamp forest in Central Kalimantan, Indonesia. In: JO Rieley and SE Page (eds). Biodiversity and Sustainability of Tropical Peatlands. Samara Publishing Ltd. Cardigan, UK, pp. 179-187.

Toyota K and M Okazaki. 2004. Effects of moisture condition and vegetation types on microbial community of tropical peat soils. Field Science Center for Northern Biosphere, Hokkaido University, Sapporo, Japan, pp. 30-41.

Widjaja-Adhi IPG. 1997 Developing tropical peatlands for agriculture. In: JO Rieley and SE Page (eds). Biodiversity and Sustainability of Tropical Peatlands. Samara Publishing Ltd. Cardigan, UK, pp. 293-300. 